\title{
PENGARUH PENDEKATAN KONFLIK KOGNITIF TERHADAP PENURUNAN MISKONSEPSI PESERTA DIDIK PADA MATERI USAHA DAN ENERGI
}

\author{
Ita Parwati*, Muh. Makhrus, I Wayan Gunada \\ Program Studi Pendidikan Fisika, Universitas Mataram \\ *Email: itaparwati1996@gmail.com
}

DOI: http://dx.doi.org/10.29303/jpft.v5i2.1316

\begin{abstract}
This study aims to determine the effect of the cognitive conflict approach to a decrease in students' misconceptions on business material and energy. This research is a quasi-experimental study with an "untreatsearch is a quasi-exed control group design withperimental study with pretest and posttest" design. The population in this study were all class X participants of SMAN 1 Gerung with Purposive Sampling sampling techniques. The experimental class (X MIPA 4) was given special treatment in the form of a cognitive conflict approach, while the control class (X MIPA 5) was not given special treatment and continued to study as before. Data on decreasing misconception were measured during learning and based on tests, both data were obtained based on the initial test and final test data. Data, when learning decreases misconception, is obtained based on the percentage decrease in misconceptions that occur. Data to test hypotheses with several variabeles in this study using the IBM SPSS 23 program with a significant $5 \%$. The results of the analysis were obtained $\sum_{\text {-count }}<t_{\text {-table }}$ so that $h_{0}$ is rejected and $h_{a}$ is accepted, so it can be concluded that there is an influence of cognitive conflict approach to a decrease in students' misconceptions.
\end{abstract}

Keywords: cognitive conflict approach; decreased misconception.

\section{PENDAHULUAN}

Pendidikan merupakan salah satu hal yang sangat penting bagi setiap individu guna mempersiapkan masa depan yang lebih baik. Tuqalby et al. (2017), menyatakan terkait dengan perkembangan zaman pendidikan harus mampu memfasilitasi peserta didik untuk dapat bersaing sesuai dengan perkembangan zaman. Sumber daya yang berkualitas hanya diperoleh melalui jalur pendidikan, oleh sebab itu diperlukan kurikulum yang baik untuk menunjang hal tersebut.

Perubahan kurikulum dari KTSP menjadi kurikulum 13 diharapkan mampu membawa perubahan di masa mendatang. Loelock (2013), menyatakan kurikulum 13 hadir sebagai kurikulum yang terintegrasi, maksudnya adalah suatu model kurikulum yang dapat mengintegrasi skill, themes, concepts, and topics baik dalam bentuk within singel disciplines, across several disciplines and within and across learners. Konsep kurikulum 13 yang terpadu dikatakan bermakna karena, peserta didik akan memahami konsep-konsep yang mereka pelajari itu secara utuh dan realistis. Kurikulum 13 juga dikatakan luas karena peserta didik akan memperoleh tidak hanya dalam satu ruang lingkup saja melainkan semua lintas disiplin yang dipandang berkaitan antar satu sama lain. Inti dari kurikulum 13 ada pada upaya penyederhanaan yang sifatnya tematikinstegratif. Kurikulum 13 disiapkan untuk mencetak generasi yang siap dalam menghadapi tantangan abad 21.

Tuntutan abad 21 membuat guru harus mampu menciptakan metode pembelajaran yang dapat mengembangkan keterampilan yang dianggap bisa memperkuat modal sosial (social capital) dan modal intelektual (intellectual capital) ini, biasa disingkat dengan 4C: communication, collaboration, critical thinking and problem solving, dan creativity and innovation. Operasional umum yang disebut 4C dijabarkan dengan 4 kategori, yakni: (1), cara berpikir, termasuk berkreasi, berinovasi, bersikap kritis, memecahkan masalah, membuat kepututusan, dan belajar pro-aktif; (2), cara bekerja, termasuk 
berkomunikasi, berkolaborasi, bekerja dalam tim; (3), cara hidup sebagai warga global dan lokal; dan (4), alat untuk mengembangkan keterampilan abad 21, yakni teknologi informasi, jaringan digital, dan literasi. Peserta didik bukanlah kertas kosong yang siap dituliskan apa saja dikarenakan peserta didik terlebih dahulu sudah memiliki pengetahuannya sendiri sebelum memasuki dunia sekolah.

Penelitian Akinbobola dan Afolabi (2010), menyatakan bahwa guru fisika harus berusaha untuk menggunakan praktik konstruktivisme melalui pendekatan penemuan dipandu dalam rangka melibatkan peserta didik dalam kegiatan pemecahan masalah, belajar mandiri, berpikir kritis dan pemahaman, dan pembelajaran kreatif, bukan dalam belajar menghafal dan menghafal. Observasi yang dilakukan di SMA Negeri 1 Gerung terhadap peserta didik kelas $\mathrm{X}$ terkait pembelajaran fisika, peserta didik rata-rata menjawab pelajaran fisika itu pelajaran yang sulit dan membosankan, karena selain hanya mendapatkan rumus mereka juga masih belajar dengan cara konvesional yang berpusat pada guru yang memberikan materi. Nilai rata-rata peserta didik ditunjukkan pada Tabel 1.

Tabel 1. Nilai Rata-Rata Ujian Fisika Semester 1 Tahun Pelajaran 2018/2019

\begin{tabular}{ccccc}
\hline No & Kelas & $\begin{array}{c}\text { Jumlah } \\
\text { Peserta Didik }\end{array}$ & $\begin{array}{c}\text { Nilai } \\
\text { Rata-Rata }\end{array}$ & KKM \\
\hline 1 & X MIPA 1 & 33 & 56,25 & \\
2 & X MIPA 2 & 32 & 53,15 & \\
3 & X MIPA 3 & 32 & 55,00 & \\
4 & X MIPA 4 & 31 & 56,12 & 75 \\
5 & X MIPA 5 & 32 & 52,78 & \\
6 & X MIPA 6 & 32 & 55,30 & \\
7 & X MIPA 7 & 32 & 48,50 & \\
\hline \multicolumn{5}{c}{ (Sember:Arsip Nilai Guru Mata Pelajaran Fisika,2018) }
\end{tabular}

Berdasarkan Tabel 1, menunjukkan bahwa nilai rata-rata ujian fisika peserta didik dimasing-masing kelas jauh dari nilai KKM yang ditentukan. Rendahnya hasil belajar peserta didik dapat dipengaruhi oleh kesalahan konsep, rendahnya kemampuan berpikir, serta masih adanya miskonsepsi. Melihat hal tersebut perlu ada tindak lanjut dengan memberikan suatu pendekatan yang tepat. Pendekatan pembelajaran yang mampu mengatasi hal tersebut adalah pendekatan konflik kognitif. Rangsangan konflik kognitif dalam pembelajaran sangat membantu proses asimilasi menjadi lebih efektif dan bermakna dalam pergulatan intelektualitas peserta didik (Setyowati, 2011). Proses pendekatan konflik kognitif dalam pembelajaran dapat dilakukan melalui beberapa fase. Lee et al. (2003) menyatakan terdapat tiga fase dalam proses pembelajaran konflik kognitif, yaitu fase permulaan (preliminary stage), fase konflik (conflict stage) dan fase penyelesaian (resolution stage). Pendekatan konflik kognitif ini diharapkan mampu meningkatkan penalaran dan pola pikir peserta didik agar dapat lebih berkembang. Peserta didik yang mempunyai kemampuan berpikir kritis yang baik diharapkan mempunyai konsep yang matang terkait dengan pembelajran fisika mengingat masih banyaknya kesalahan konsep pada peserta didik disetiap materi.

Penelitian yang dilakukan pada materi usaha dan energi di bawah ini menunjukkan masih rendahnya konsep yang dimiliki peserta didik. Rahmatina et al. (2018) menyatakan kesulitan yang dialami peserta didik pada konsep hubungan usaha dengan energi potensial sistem yaitu peserta didik salah memaknai hubungan usaha oleh gaya gravitasi dengan ketinggian benda pada bidang miring. Soal tersebut menyatakan bahwa pemain ski menuruni lereng es dengan lintasan seperti pada Gambar 1 peserta didik diminta menentukan perbandingan usaha oleh gaya gravitasi bumi terhadap pemain ski saat dari A ke B serta dari B ke C. Peserta didik lebih banyak menjawab $W_{A B}=\frac{1}{2} W_{B C}$ dengan alasan Panjang lintasan $\mathrm{AB}$ yaitu $\frac{1}{2}$ kali lintasan $\mathrm{AC}$. 
Jawaban peserta didik tersebut salah. Peserta didik seharusnya meninjau ketinggian yang dicapai pemain ski. Saat dari posisi A ke B menempuh ketinggian yang sama ketika dari B ke C yaitu sebesar $h$. Jadi, usaha oleh gaya gravitasi terhadap pemain ski dari A ke B sama dengan saat dari B ke $C$ yaitu sebesar $m g h$.

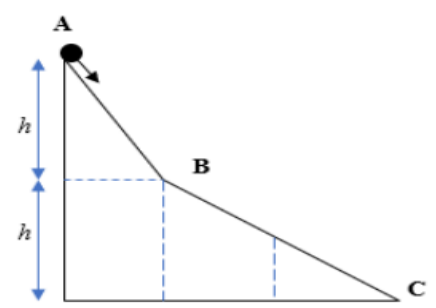

Gambar 1. Lintasan yang Ditempuh Pemain Ski Sumber: Rahmatina et al. (2018).

Permasalahan seperti di atas membuat pendidik harus mencari tahu faktor-faktor penyebabnya. Smith et al. 1993 (dalam Makhrus, 2018) menyatakan bahwa miskonsepsi berasal dari pembelajaran peserta didik sebelumnya baik di kelas atau dari interaksi dengan dunia sosial dan fisika. Pandangan ini dapat dilihat dari keyakinan mengenai miskonsepsi "gaya menyebabkan terjadinya sebuah gerak" yang tertanam dalam pengalaman-pengalaman motorik ketika peserta didik mendorong ataupun menarik benda-benda. Pembelajaran fisika seharusnya dititik beratkan pada upaya penggantian miskonsepsi-miskonsepsi yang dialami peserta didik dengan konsep para ahli (konsep ilmiah).

Baser (2006) menyatakan faktor penyebab rendahnya tingkat pemahaman peserta didik terhadap konsep-konsep fisika berasal dari faktor internal peserta didik. Peserta didik menghadapi masalah dalam kehidupan sehari-hari, mereka akan menanganinya berdasarkan konsep naif yang dimiliki. Pendekatan pembelajaran yang sesuai dengan karaktristik peserta didik diharapkan dapat mengatasi masalah tersebut. Metode pendekatan pembelajaran dalam mengetahui lemahnya pemahaman konsep, kemampuan berpikir kritis dan miskonsepsi peserta didikpun harus dipikirkan agar dapat diketahi sejauh mana kemampuan peserta didik.

Penentuan metode yang digunakan dalam mengetahui tingkat miskonsepsi peserta didik harus tepat. Metode yang tepat dalam mengetahui miskonsepsi peserta didik adalah metode CRI. Metode Certainty of Response Index (CRI) ini digunakan untuk mengidentifikasi terjadinya miskonsepsi sekaligus dapat membedakannya dengan tidak tahu konsep dan paham konsep. Metode ini merupakan alat yang digunakan untuk mengukur tingkat keyakinan/kepastian responden dalam menjawab setiap soal/pertanyaan yang diberikan (Hasan, 1999). CRI ini digunakan untuk menentukan suatu tingkat kepastian pada setiap jawaban peserta didik yang berdasarkan pada suatu skala $0-5$. Skala ini dimulai dari jawaban menebak sampai peserta didik yakin menjawab pertanyaan. Mengatasi miskonsepsi memang bukan hal yang mudah sehingga perlu pendekatan yang benar-benar sesuai sehingga miskonsepsi yang terjadi pada peserta didik dapat dikurangi, dan salah satu pendekatan yang diharapkan mampu mengurangi miskonsepsi adalah pendekatan konflik kognitif.

Berg (1991) dalam penelitiannya menyatakan bahwa pendekatan konflik kognitif dalam pembelajaran fisika cukup efektif untuk mengatasi miskonsepsi pada peserta didik dalam rangka membentuk keseimbangan ilmu yang lebih tinggi. Rangsangan konflik kognitif dalam pembelajaran fisika akan sangat membantu proses asimilasi menjadi lebih efektif dan bermakna, sehinga pendekatan konflik kognitif perlu dilakukan dalam strategi pembelajaran fisika (dalam Mozik dan Maulana, 2010). 
Makhrus (2014) menyatakan pendekatan konflik kognitif dapat menciptakan ketidakpuasan terhadap pikiran peserta didik mengenai konsepsi alternatif yang dimilikinya, yang disebut dengan konflik kognitif, yang diikuti dengan penguatan status konsepsi ilmiah yang diinginkan sehingga mampu mempermudah peserta didik dalam proses perubahan konseptual terhadap konsepsi-konsepsi alternatif yang mereka miliki. Pendekatan konflik kognitif akan dapat membuat peserta didik benar-benar dapat merasa puas dengan pembelajaran yang dilakukan (dapat terjadi perubahan konseptual) karena adanya pembahasan rinci dari fenomena yang membingungkan dan ditunjukkan bagaimana konsepsi ilmiah dapat berlaku. Pembelajaran dengan pendekatan yang dilakukan ini tidak menyisakan miskonsepsi-miskonsepsi yang dapat menjadi penghambat prestasi belajar peserta didik.

Penelitian ini bertujuan untuk mendeskripsikan dan mengetahui tingkat penurunan miskonsepsi peserta didik setelah diajarkan menggunakan pendekatan konflik kognitif dengan menggunakan teknik CRI (Certain of Response Index) pada materi usaha dan energi dan dilanjutkan dengan uji hipotesis menggunakan uji manova.

\section{METODE PENELITIAN}

Jenis penelitian yang digunakan adalah kuasi eksperimen dengan desain penelitian yang digunakan adalah untreated control group design with pretest and posttes. Populasi dalam penelitian ini adalah seluruh peserta didik kelas $\mathrm{X}$ tahun ajaran 2018 Jumlah seluruh peserta didik kelas X adalah 284 peserta didik yang terbagi ke dalam 7 kelas.

Teknik pengambilan sampel menggunakan teknik Purposive Sampling. Penelitian ini menggunakan kelas X MIPA 4 sebagai kelas ekperimen dan kelas X MIPA 5 sebagai kelas kontrol.

Penurunan miskonsepsi diukur menggunakan teknik CRI yang terdiri dari 8 soal uraian yang kemudian diujikan pada tes awal dan tes akhir, dan untuk data dalam pengujian hipotesis menggunakan uji manova untuk mengetahui apakah terdapat pengaruh pendekatan konflik kognitif terhadap penurunan miskonsepsi peserta didik pada materi usaha dan energi.

\section{HASIL DAN PEMBAHASAN}

Pendektan pengajaran utama yang berdasarkan pada konstruktivisme adalah pendektan konflik kognitif. Pendektan konflik kognitif menurut beberapa ahli. Lee et al. (2001) Pendektan konflik kognitif adalah sebuah keadaan dimana siswa merasa adanya ketidakcocokan antara strukur kognitif mereka dengan keadaan lingkungan sekitarnya. Sejalan dengan itu, Fraser (dalam Zulkarnain, 2013) konflik kognitif adalah kesadaran individu tentang informasi yang bertentangan yang berdampak pada sebuah konsep pada struktur kognitif itu sendiri.

Penelitian ini tidak hanya mengukur hasil dari sebuh perlakuan melainkan juga mengukur persentase penurunan miskonsepsi pada kelompok peserta didik dengan menggunkan teknik CRI yang terdiri dari kelas ekperimen dan kelas kontrol saat proses pembelajaran dengan menggunakan intrumen tes awal (pretest) dan tes akhir (posttest). Penurunan miskonsepsi dilihat selama tes awal (pretest) dan tes akhir (posttest) diberikan pada kelas ekperimen dan kelas kontrol dan akan dikelompokkan berdasarkan 3 kategori yakni Tidak Tahu Konsep (TTK), Miskonsepsi (M), dan Memahami Konsep (MK). Pemilihan soal yang tepat untuk dijadikan instrumen soal uraian untuk mengetahui tingkat miskonsepsi dan penurunan miskonsepsi peserta didik juga sangat penting guna 
mendapatkan hasil yang sesuai dengan apa yang akan diteliti.

Kelas kontrol pada saat tes awal (pretest) memiliki persentase yang berbeda pada setiap sub materinya. Dapat dilihat pada Gambar 2.

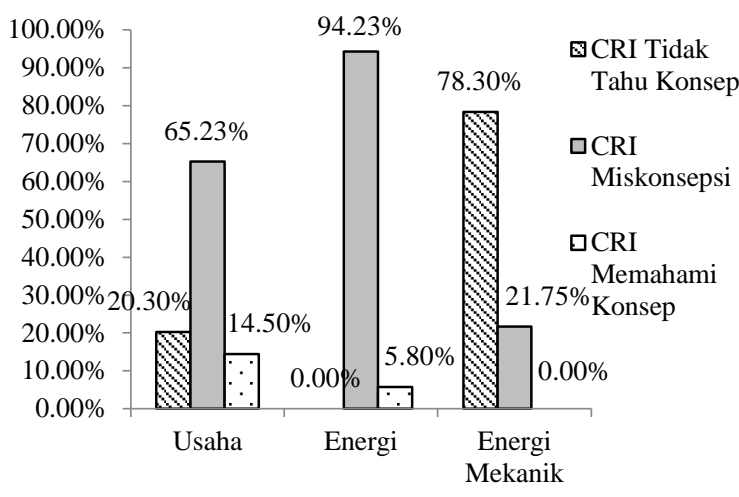

Gambar 2. CRI Penurunan Miskonsepsi Peserta Didik Kelas Kontrol pada Tes Awal

Data pada Gambar 2 di atas menunjukkan bahwa persentase pada kategori tidak tahu konsep dan miskonsepsi memiliki persentase yang cukup besar, hal tersebut karena peserta didik memilih tingkat kepercayaan yang cukup tinggi pada saat memilih skala tingkat keyakinan yang disajikan, itu tandanya peserta didik sangat yakin dengan pengetahuan awal mereka.

Tes akhir (posttest) data penurunan miskonsepsi diperoleh pada setiap sub materi memiliki persentase penurunan miskonsepsi yang berbeda pula pada setiap sub materi. Dapat dilihat pada Gambar 3 berikut.

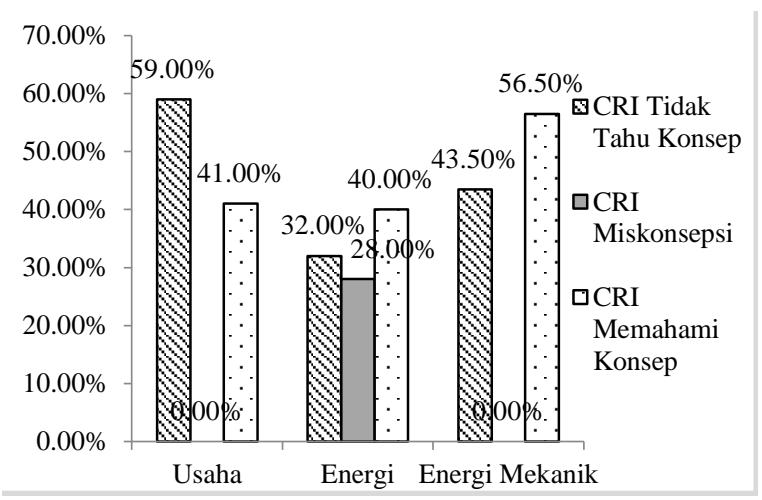

Gambar 3. CRI Penurunan Miskonsepsi Peserta Didik Kelas Kontrol pada Tes Akhir
Data yang diperoleh dari posttes ini menunjukkan penurunan pada kategori miskonsepsi, kemudian terjadi peningkatan pada kategori tidak tahu konsep dan kategori memahami konsep. Kategori tidak tahu konsep meningkat cukup signifikan terutama pada sub materi usaha, hal tersebut terjadi karena beberapa faktor diantaranya peserta didik banyak yang menjawab salah. Contohnya pada butir soal nomor satu soal dapat dilihat pada lampiran 10 yang ditanyakan adalah besar usaha oleh gaya gravitasi terhadap pemain ski yang meluncur dari A ke B kemudian dari B ke $\mathrm{C}$ dengan lintasan yang berbeda namun ketinggian sama, disini peserta didik banyak yang menjawab berbeda karena peserta didik cenderung melihat lintasannya, seharusnya jawaban yang benar adalah usaha yang dilakukan sama karena ketinggiannya sama, maka berlaku juga gaya konservatif dimana untuk gaya konservatif sendiri usaha tidak bergantung pada lintasan dan hanya bergantung pada keadaan awal dan keadaan akhir.

Sub materi energi mengalami penurunan pada kategori miskonsepsi dan mengalami peningkatan pada kategori tidak tahu konsep dan kategori memahami konsep. Hal tersebut juga terjadi karena sumbangan dari persentase peserta didik yang awalnya mengalami miskonsepsi menjadi tidak tahu konsep. Peserta didik yang awalnya yakin dengan konsep awalnya kemudian setelah diberikan materi usaha dan energi terjadi perubahan konsep akan tetapi peserta didik yang masih kurang paham akan memberikan jawaban dengan kurang memuaskan dan akibatnya skala tingkat keyakinan yang diberikan pada CRI pun masih akan rendah dan akan berdampak pada pengelompokan untuk CRI itu sendiri.

Jawaban peserta didik yang masih banyak keliru juga ada pada butir soal nomor 5 yang diperlihatkan pada Gambar 4 berikut. 


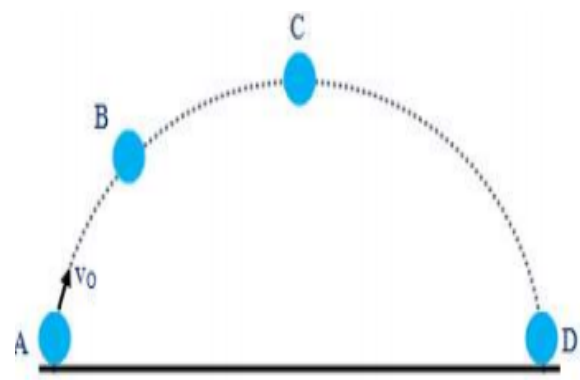

Gambar 4. Benda yang di Tendang Hingga Membentuk Lintasan Parabola

Sebuah benda ditendang dengan sudut elevasi tertentu sehingga lintasannya membentuk sudut parabola seperti pada gambar di atas. Berdasarkan lintasan tersebut, di posisi A, B, C adan D manakah posisi yang memungkinkan bola memiliki energi kinetik paling kecil? Peserta didik banyak yang menjawab posisi A dan D adalah posisi yang memiliki energi kinetik paling kecil, seharusnya jawaban yang tepat adalah di posisi $\mathrm{C}$, dengan alasan energi kinetik berbanding lurus dengan kuadrat kecepatan benda. Ketika bola bergerak dengan membentuk lintasan parabola seperti pada gambar yang telah ditampilkan pada soal, maka kecepatan bola semakin ke atas semakin kecil, dengan demikian bola memiliki kecepatan paling kecil pada saat bola mencapai titik tertingginya. Faktor selanjutnya yang mempengaruhi kategori tidak tahu konsep meningkat yaitu peserta didik berpikir dua kali untuk memilih skala tingkat keyakinan pada CRI karena peserta didik sudah diberikan materi sebelumnya, sebelum diujikan kembali. Jadi ketika peserta didik merasa jawabannya kurang tepat maka skala tingkat keyakinan yang diberikan oleh peserta didik akan semakin kecil.

Melihat data dari kelas kontrol yang mengalami peningkatan pada kategori tidak tahu konsep yang awalnya sebesar 32,86\% menjadi $44,96 \%$ maka peneliti melakukan wawancara terhadap beberapa peserta didik yang memiliki jawaban benar akan tetapi CRI yang diberikan rendah dan terhadap peserta didik yang memiliki jawaban salah dan CRI rendah, hasil yang didapatkan adalah peserta didik yang menjawab benar namun CRI rendah beralasan pada saat menjawab soal dan pada saat memilih skala CRI yang disediakan hanya asal mencentang, dan peserta didik yang menjawab salah kemudian CRI yang diberikan rendah juga menjawab tidak terlalu menghiraukan skala tingkat keyakinan CRI yang disediakan dan kurang belajar. Peneliti juga menganalisis bahwa faktor yang menyebabkan peserta didik dengan jawaban benar akan tetapi CRI rendah adalah peserta didik yang kemungkinan hanya mengikuti jawaban temannya (mencontek), dan bisa juga peserta didik yang sudah menjawab dengan benar akan tetapi memiliki tingkat kepercayaan yang kurang sehingga memberikan skala tingkat keyakinan yang kurang pada CRI. Hal tersebut juga sejalan dengan pernyataan Aliefman (2012) (dalam Mustaqim et al. 2014), yang menyatakan adanya peserta didik yang sebenarnya mampu menjawab dan memahami konsepkonsep yang terdapat pada soal, namun karena memiliki tingkat keyakinan yang rendah menuntunnya memiliki skala CRI yang rendah, sehingga .dikelompokkan dalam kategori tidak paham konsep atau hanya mengikuti jawaban teman. Penggunaan teknik CRI dalam hal ini sangat bergantung juga dengan kepercayaan dan kejujuran dari peserta didik itu sendiri.

Kelas ekperimen pada saat tes awal (pretest) memiliki persentase yang berbeda pada setiap sub materinya. Dapat di lihat pada Gambar 5 berikut. 


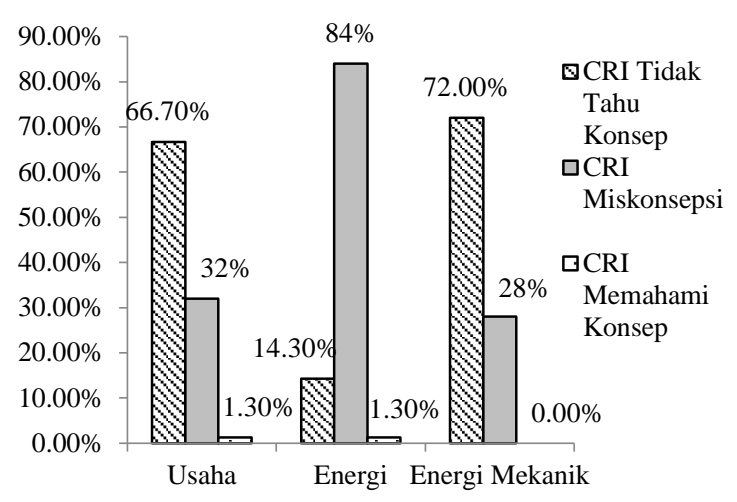

Gambar 5. CRI Penurunan Miskonsepsi Peserta Didik Kelas Ekperimen pada Tes Awal

Data yang diperoleh pada gambar di atas menunjukkan kategori tidak tahu konsep dan miskonsepsi yang cukup besar dibandingkan dengan kategori memahami konsep, hal tersebut terjadi karena peserta didik memiliki tingkat keyakinan yang tinggi pada pengetahuan awal mereka mengenai materi usaha dan energi ini sehingga skala tingkat keyakinan yang diberikan pada CRI pun akan tinggi.

Data pada saat (posttest) penurunan miskonsepsi diperoleh pada setiap sub materi memiliki persentase penurunan miskonsepsi yang berbeda pula pada setiap sub materi. Dapat di lihat pada Gambar 5 berikut.

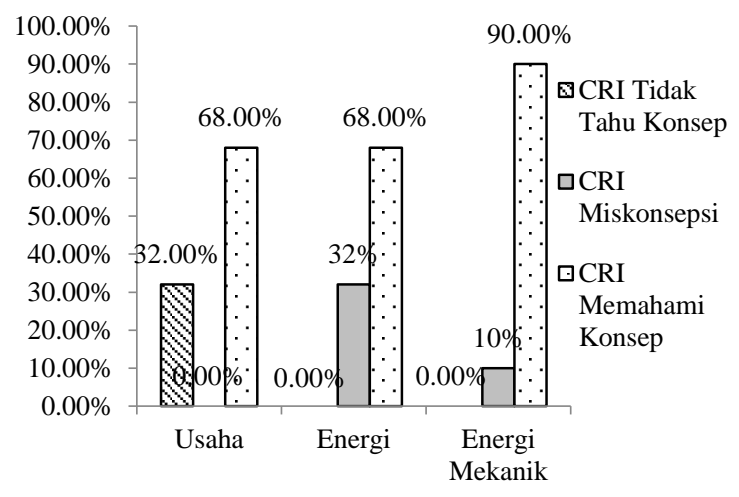

Gambar 6. CRI Penurunan Miskonsepsi Peserta Didik Kelas Ekperimen pada Tes Akhir

Data yang diperoleh tersebut menunjukkan terjadi penurunan miskonsepsi yang cukup signifikan, hal tersebut dikarenakan peserta didik sudah memiliki konsep baru setelah diajarkan materi tersebut menggunakan pendekatan konflik kognitif, sehingga ketika peserta didik diberikan tes dengan materi usaha dan energi maka peserta didik pada saat memberikan jawaban dengan yakin maka skala tingkat keyakinan pada CRI yang diberikan oleh peserta didik akan semakin tinggi dan ketika peserta didik merasa ragu akan jawabannya maka peserta didik akan memberikan skala keyakinan pada CRI pun akan rendah.

Sebagai contoh pada sub materi Hukum Kekekalan Energi Mekanik. Peserta didik diberikan soal yang menyatakan "Bila hukum kekekalan energi mekanik untuk sisitem berlaku, maka manakah pernyataan yang benar? Jelaskan!" dan dari 5 opsi yang diberikan pada saat pretest peserta didik banyak yang menjawab jumlah energi potensial dan energi kinetik sistem selalu bertambah dengan alasan energi didunia selalu digunakan dan jumlah yang digunakan akan selalu bertambah, namun setelah diberikan pemahan terkait sub materi energi mekanik rata-rata peserta didik pada saat posttest telah mengalami perubahan pengetahuan sehingga jawabnnya menjadi "Jumlah energi potensial dan energi kinetik sistem selalu tetap" dengan alasan, energi mekanik adalah jumlah energi potensial dan energi kinetik yang dimiliki oleh suatau benda.

Hukum kekekalan energi mekanik, menyatakan: energi tidak dapat diciptakan dan dimusnahkan melainkan hanya mengalami perubahan bentuk, dengan demikian, menurut hukum kekekalan energi mekanik, energi mekanik pada kondisi pertama akan sama dengan energi mekanik pada kondisi kedua. Artinya, jika hukum kekekalan energi mekanik berlaku pada suatu sistem akan tetap. Pada saat energi potensialnya berkurang, maka energi kinetiknya akan bertambah sehingga jumlahmya akan tetap sama. Begitu pula sebaliknya, saat energi potensial bertambah, maka energi kinetiknya akan berkurang dan 
energi mekaniknya akan sama dengan energi mekanik mula-mula. Melihat jawaban peserta didik dari pretest dengan posttest yang telah mengalami perubahan maka hal itu menandakan bahwa telah terjadi perubahan konseptual akibat dari pemberian materi pembelajaran yang menggunkan pendekatan konflik kognitif.

Data yang diperoleh tersebut menandakan bahwa terdapat pengaruh pendekatan konfliki kognitif terhadap penurunan miskonsepsi peserta didik. Hasil ini sesuai dengan pendapat Baser (2006) \& Sirait (2012) yang menyatakan pendekatan konflik kognitif dapat meningkatkan penguasaan konsep fisika peserta didik lebih signifikan dibandingkan dengan model konvensional. Sejalan dengan itu (Berg, 1991) juga menyatakan pendekatan konflik kognitif dalam pembelajaran fisika cukup efektif dalam mengatasi miskonsepsi pada peserta didik dalam rangka membentuk keseimbangan ilmun yang lebih tinggi. Adnyani et al. (2013) menyatakan kelompok peserta didik yang mendapatkan penerapan pembelalajaran dengan Strategi Pendekatan Konflik Kognitif mengalami penurunan miskonsepsi yang lebih baik dibandingkan kelompok Strategi Pendekatan Konvensional untuk masing-masing tipe miskonsepsi.

Temuan hasil uji manova yang menunjukkan data signifikan hasil penelitian yang lebih kecil dari 0,05 yang artinya terdapat pengaruh pendekatan konflik kognitif terhadap penurunan miskonsepsi peserta didik pada materi usaha dan energi. Data yang diperoleh tersebut sesuai dengan penelitian sebelumnya yaitu (Sukariasih, 2016), yang menyatakan bahwa setelah pembelajaran dengan pendekatan konflik kognitif melalui anomali data atau contohcontoh soal yang bertentangan dengan konsep awal peserta didik yang disertai dengan demonstrasi, diskusi dan eksperimen dapat memberikan dampak positif yang sangat besar terhadap perubahan pemahaman konsep gerak lurus pada diri peserta didik sehingga terdapat penurunan miskonsepsi peserta didik.

\section{PENUTUP}

Berdasarkan hasil dan pembahasan yang telah dipaparkan dapat disimpulkan bahwa: 1) Penurunan miskonsepsi peserta didik pada saat pembelajaran fisika materi usaha dan energi pada kelas eksperimen maupun kelas kontrol mengalami penurunan. 2) Terdapat pengaruh pendekatan konflik kognitif terhadap penurunan miskonsepsi peserta didik setelah diajarkan menggunakan pendekatan konflik kognitif peserta didik pada materi usaha dan energi.

\section{REFERENSI}

Akinbobola, A. O. \& Afolabi, F. 2010. Constructivist practices through guided discovery approach: The effect on students' cognitive achievement in Nigerian senior secondary school physics. Eurasian Journal Physic Chemistry Education.

Adnyani, W. N,. Sadia W. I. \& Natajaya N. I. 2013. Pengaruh Strategi Pembelajaran Konflik Kognitif Terhadap Penurunan Miskonsepsi Fisika Ditinjau dari Gaya Kognitif Siswa Kelas X Di SMA Negeri 1 Bebandem. Jurnal Program Pascasarjana Universitas Pendidikan Ganesha. 4.

Baser, M. 2006. Fostering conceptual change by cognitive conflict based instruction on students' understanding of heat and temperature concepts. Eurasia Journal of Mathematics, Science and Technology Education, 2(2), 96-114.

Berg, E.V.D. 1991. Miskonsepsi Fisika dan Remediasi. Salatiga : Universitas Kristen Satya Wacana (UKSW). 
Hasan, S,. Bagayoka, D,.Kelley, L H. 1999. Misconception and The Certainty of Response Index (CRI). Physics Education 34(5).

Lee, G., Kwon, J., Park, S. S., Kim, J. W., Kwon, H. G., \& Park, H. K. 2003. Development of an instrument for measuring cognitive conflict in secondary level science classes. Journal of research in science teaching, 40(6), 585-603.

.2001. What Do We Know about Students' Cognitive Conflict in Science Classroom: A Theoretical Model of Cognitive Conflict Process.1-19.

Loelock, E. P., \& Sopan, A. 2013. Panduan Memahami Kurikulum 2013. Jakarta: PT Prestasi Pustakarya.

Makhrus, M. Nur, M., \& Widodo, W. 2014. Model Perubahan Konseptual dengan Pendekatan Konflik Kognitif (MPK-PKK). Jurnal Pijar MIPA. 9(1).

Makhrus, M. Widodo, W., \& Agustini R. 2018. Efektifitas Model Pembelajaran CCM-CCA untuk Memfasilitasi Perubahan Konsep Gaya pada Mahasiswa. Jurnal Pendidikan Fisika dan Teknologi. 4(2).

Mosik., \& Maulana, P. 2010. Usaha Mengurangi terjadinya miskonsepsi fisika melalui pembelajaran dengan pendekatan konflik kognitif. Jurnal Pendidikan Fisika Indonesia. 6 (1), 98-103.

Mustaqim, A,D., Zulfiani., \& Herlanti Y. 2014. Identifikasi Miskonsepsi Siswa dengan Menggunakan Metode Certainty of Respondense Index (CRI) pada Konsep Fotosintesis dan Respirasi Tumbuhan. Jurusan Pemdidikan Biologi FITK UIN Syarif Hidayatullah, 6 (2), 146-152.

Rahmatina, I., Desella, Sutopo, \& Wartono. Identifikasi Kesulitan Siswa SMA pada Materi Usaha dan Energi.
Jurusan S2 Pendidikan Fisika, Universitas Negeri Malang, Indonesia, 2 (1), 8-14.

Setyowati, A., Subali, B., \& Mosik. 2011. Implementasi pendekatan konflik kognitif dalam pembelajaran fisika untuk menumbuhkan kemampuan berpikir kritis siswa SMP kelas VIII. Jurnal Pendidikan Fisika Indonesia, 7(2),89-96.

Sukariasih, L. 2016. The Use of Cognitive Conflict Strategy to Reduce Student Misconceptions on The Subject Matter of Rictilinear Motion. International Journal of Education and Literature. 4 (7), 483-492.

Tuqalby, R., Surio, \& Gunawan. 2017. Pengaruh Strategi Konflik Kognitif terhadap Penguasaan Konsep pada Materi Fluida Siswa Sman 3 Maaram Tahun Ajaran 2016/2017. Jurnal Pendidikan Fisika dan Teknologi, 3(1), 8-13.

Zulkarnain, I. 2013. Perangkat Soal Berbasis Konflik Kognitif. Jurnal Pendidikan Matematika, 1(1), 1-8. 